\title{
Multi-Scale Evaluation of the Effect of Phenol Formaldehyde Resin Impregnation on the Dimensional Stability and Mechanical Properties of Pinus Massoniana Lamb.
}

\author{
Xinzhou Wang ${ }^{1}{ }^{\mathbb{D}}$, Xuanzong Chen ${ }^{1}$, Xuqin Xie ${ }^{2}$, Shaoxiang Cai ${ }^{1}$, Zhurun Yuan ${ }^{1}$ and \\ Yanjun $\mathrm{Li}^{1}{ }^{1}$ * \\ 1 College of Materials Science and Engineering, Nanjing Forestry University, Nanjing 210037, China \\ 2 Dehua Tubao New Decoration Material Co., Ltd., Zhejiang 313200, China \\ * Correspondence: lalyj@njfu.edu.cn; Tel.: +86-025-85428507
}

Received: 1 July 2019; Accepted: 27 July 2019; Published: 31 July 2019

\begin{abstract}
The local chemistry and mechanics of the control and phenol formaldehyde (PF) resin modified wood cell walls were analyzed to illustrate the modification mechanism of wood. Masson pine (Pinus massoniana Lamb.) is most widely distributed in the subtropical regions of China. However, the dimensional instability and low strength of the wood limits its use. Thus, the wood was modified by PF resin at concentrations of $15 \%, 20 \%, 25 \%$, and $30 \%$, respectively. The density, surface morphology, chemical structure, cell wall mechanics, shrinking and swelling properties, and macro-mechanical properties of Masson pine wood were analyzed to evaluate the modification effectiveness. The morphology and Raman spectra changes indicated that PF resin not only filled in the cell lumens, but also penetrated into cell walls and interacted with cell wall polymers. The filling and diffusing of resin in wood resulted in improved dimensional stability, such as lower swelling and shrinking coefficients, an increase in the elastic modulus $\left(E_{\mathrm{r}}\right)$ and hardness $(H)$ of wood cell walls, the hardness of the transverse section and compressive strength of the wood. Both the dimensional stability and mechanical properties improved as the PF concentration increased to $20 \%$; that is, a PF concentration of $20 \%$ may be preferred to modify Masson pine wood.
\end{abstract}

Keywords: Pinus massoniana Lamb.; phenol formaldehyde resin; wood impregnation; wood properties; cell-wall mechanics

\section{Introduction}

Pinus massoniana Lamb., commonly known as Masson pine, is one of the most widely distributed tree species in the subtropical regions of China [1]. The wood from Masson pine planted forests has become an important industrial raw material for wide commercial use such as wood construction, wood-based panels, and polymer composites due to the beautiful wood grain, good adaptability to the environment, and shorter growth cycle [2,3]. However, as one of the common fast-growing tree species, Masson pine wood also presents drawbacks which limit its practical application, such as low dimensional stability, softness, and low bio-durability [4,5]. In the past few decades, a number of modification methods have been proposed to enhance the quality and high value-added utilization of plantation wood, including thermal or densification treatment, surface coating, and chemical impregnation [6-10]. Above all, chemical impregnation under vacuum or pressure has been proven to be an effective method to improve the properties of the wood. Among the existing chemical modification methods, impregnating and curing the wood with resins appears to especially promote the industrial utilization of wood [11,12]. 
Phenol formaldehyde (PF) resin is a popular thermosetting agent that forms a three dimensional structure via cross-linking reactions after curing, which are extensively used in exterior grade wood-based panels for its excellent performance, including water resistance and chemical stability [13-15]. It has therefore been widely used to improve dimensional stability and strength and prolong the service life of wood for indoor and outdoor use [16-18]. To date, changes in physical, mechanical, and chemical properties of chemically modified wood have been intensively analyzed at the macro scale $[19,20]$. The modified wood achieved high dimensional and stiffness stability and biological resistance. Monomers such as methyl methacrylate, styrene-methyl methacrylate and styrene-glycidyl methacrylate have been utilized for wood modification and have proven that the monomers not only filled in the cell lumens, but also penetrated into the cell walls [21,22]. However, for a pre-polymer like PF resin with a higher molecular weight, it is still unclear whether it can penetrate into cell wall or not, or what the accompanied influence on the cell wall would be. In particular, only limited attempts have been made to find out the correlations between chemical, physical, and mechanical performance between the cell wall- and macro-level to indicate the contribution of cell wall modification. Nanoindentation (NI) has been successfully applied for measuring the mechanics of wood cell walls including modulus of elasticity, hardness, etc. [23-25] and the Raman spectra technique can detect the local chemical structure of wood cell walls [26], which facilitates in situ characterization of the effects of PF resin impregnation on wood cell walls.

The purpose of this study was to characterize the properties of PF resin modified Masson pine wood for enriching the fundamental theory of wood chemical modification, which may benefit the modification process. For this purpose, the changes in morphology, local chemical structure and mechanics at the cell wall level and the density, dimensional stability, and mechanical properties at the macro-scale of Masson pine wood after PF resin impregnation were analyzed using scanning electron microscopy (SEM), Raman, NI, and conventional physical and mechanical test instruments, respectively.

\section{Materials and Methods}

\subsection{Materials}

Wood samples were obtained from 40-year-old Masson pine (Pinus massoniana Lamb.) wood harvested from plantation forestry located in Fujian Province, China. Wood blocks with the dimensions $20 \mathrm{~mm}^{3} \times 20 \mathrm{~mm}^{3} \times 160 \mathrm{~mm}^{3}$ and $50 \mathrm{~mm}^{3} \times 50 \mathrm{~mm}^{3} \times 70 \mathrm{~mm}^{3}$ (longitudinal $\times$ tangential $\times$ radial) were cut from the sapwood around the 21st growth ring. The initial moisture content was about $11 \%$. A commercial phenol formaldehyde (PF) resin (Dynea Co., Ltd., Guangdong, China) with a solid content of $48 \%$ and a viscosity of $150 \mathrm{mPa} \cdot \mathrm{s}$ at $25^{\circ} \mathrm{C}$ was used in this experiment.

\subsection{Impregnation Treatment}

The wood samples were oven-dried at $103 \pm 2{ }^{\circ} \mathrm{C}$ until a constant weight was achieved, and the weight was determined before impregnation. The PF resin was diluted with distilled water into resin concentrations of $15 \%, 20 \%, 25 \%$, and $30 \%$ for separate treatments. Twenty replicate samples in each treatment group were conducted in a stainless-steel chamber under a vacuum of $0.09 \mathrm{MPa}$ for $30 \mathrm{~min}$ and then at $0.8 \mathrm{MPa}$ for $2 \mathrm{~h}$. After impregnation, the samples were air-dried at room temperature for $48 \mathrm{~h}$ after removing the excess resin on the surface, and then were cured at a temperature of $130{ }^{\circ} \mathrm{C}$ for $2 \mathrm{~h}$ in an oven.

\subsection{Determination of Weight Percent Gain and Density}

The oven-dried weight and volume of the 20 replicate samples with the dimensions $20 \mathrm{~mm}^{3} \times 20$ $\mathrm{mm}^{3} \times 20 \mathrm{~mm}^{3}(\mathrm{~L} \times \mathrm{T} \times \mathrm{R})$ cut from the PF resin modified wood were determined to calculate the 
oven-dried density and weight percent gain (WPG) of the samples. The WPG was calculated according to Equation (1):

$$
W P G(\%)=\frac{W_{1}-W_{0}}{W_{0}} \times 100 \%
$$

where $W_{1}$ is the oven-dried weight of the modified wood and $W_{0}$ is the oven-dried weight of the control wood.

\subsection{Morphology Observation}

Both the cross-section and tangential section of the surfaces of the control and modified wood samples were observed using scanning electron microscopy (SEM, JSM-7600F, JEOL Japan Electronics Co., Ltd., Japan) at an accelerating voltage of $20 \mathrm{kV}$.

\subsection{Raman Measurement}

The local chemical distribution analysis in the transversal section of the control and modified wood samples was analyzed by a laser Raman spectrometer (DXR532, Thermo Fisher Scientific Inc., USA) equipped with a linear-polarized $780 \mathrm{~nm}$ laser. The cross-sections of the wood samples were sliced by an ultra-microtome (Leica MZ6, Germany) with a thickness of $20 \mu \mathrm{m}$ and then placed on glass slides covered with glass coverslips. All spectra were collected in the range of $1800 \mathrm{~cm}^{-1}$ to $600 \mathrm{~cm}^{-1}$.

\subsection{Dimensional Stability Analysis}

The dimensions $(\mathrm{L} \times \mathrm{T} \times \mathrm{R})$ of the control and modified wood samples were measured under three different moisture contents ( $>$ fiber satruated point, air-dried, and oven-dried) to analyze the dimensional stability according to the testing procedure of Chinese National Standards (GB/T 1932-2009 and GB/T 1934.2-2009). For determination of shrinkage, samples were soaked in distilled water at $20{ }^{\circ} \mathrm{C}$ until the dimension was constant, and then the wet samples were conditioned at $20{ }^{\circ} \mathrm{C}$ and relative humidity (RH) of $65 \%$, and finally the air-dried samples were dried in an oven at $103{ }^{\circ} \mathrm{C}$ until a constant weight was achieved. In contrast, the determination of swelling was processed in reverse order. The swelling coefficient $(\alpha)$, shrinkage coefficient $(\beta)$, anti-swelling efficiency (ASE), and anti-shrinking efficiency (ASE') can be calculated by Equations (2)-(13):

$$
\begin{gathered}
\alpha_{w}(\%)=\frac{l_{\mathrm{w}}-l_{0}}{l_{0}} \times 100 \% \\
\alpha_{\max }(\%)=\frac{l_{\max }-l_{0}}{l_{0}} \times 100 \% \\
\alpha_{V w}(\%)=\frac{V_{\mathrm{w}}-V_{0}}{V_{0}} \times 100 \% \\
\alpha_{V \max }(\%)=\frac{V_{\max }-V_{0}}{V_{0}} \times 100 \% \\
\operatorname{ASE}_{w}(\%)=\frac{\alpha_{V w(c)}-\alpha_{V w(m)}}{\alpha_{V w(c)}} \times 100 \% \\
\operatorname{ASE}_{\max }(\%)=\frac{\alpha_{V \max (c)}-\alpha_{V \max (m)}}{\alpha_{V \max (c)}} \times 100 \%
\end{gathered}
$$

where $\alpha_{\mathrm{w}}$ and $\alpha_{\max }$ are the linear swelling coefficient from oven-dried to air-dried and from oven-dried to wet, respectively; $l_{\max }, l_{\mathrm{w}}$, and $l_{0}$ are the length in the tangential and radial directions of wet, air-dried, and oven-dried samples, respectively; similarly, $\alpha_{V w}$ and $\alpha_{V \max }$ are the volumetric swelling coefficients; 
$V_{\max }, V_{\mathrm{w}}$, and $V_{0}$ are the volume of samples at different moisture conditions; $\alpha_{V \mathrm{w}(\mathrm{c})}$ and $\alpha_{V \max (\mathrm{m})}$ are the volumetric swelling coefficient of the control and modified wood samples, respectively.

$$
\begin{gathered}
\beta_{\max }(\%)=\frac{l_{\max }-l_{0}}{l_{\max }} \times 100 \% \\
\beta_{w}(\%)=\frac{l_{\max }-l_{\mathrm{w}}}{l_{\max }} \times 100 \% \\
\beta_{V \max }(\%)=\frac{V_{\max }-V_{0}}{V_{\max }} \times 100 \% \\
\beta_{V w}(\%)=\frac{V_{\max }-V_{\mathrm{w}}}{V_{\max }} \times 100 \% \\
\operatorname{ASE}_{\max }^{\prime}(\%)=\frac{\beta_{V \max (c)}-\beta_{V \max (m)}}{\beta_{V \max (c)}} \times 100 \% \\
\operatorname{ASE}_{w}^{\prime}(\%)=\frac{\beta_{V w(c)}-\beta_{V w(m)}}{\beta_{V w}(c)} \times 100 \%
\end{gathered}
$$

where $\beta_{\max }$ and $\beta_{\mathrm{w}}$ are the linear shrinking coefficient from oven-dried to air-dried and from oven-dried to wet, respectively; $l_{\max }, l_{\mathrm{w}}$, and $l_{0}$ are the length in the tangential and radial directions of oven-dried, air-dried, and wet samples, respectively; similarly, $\beta_{V \max }$ and $\beta_{V \mathrm{w}}$ are the volumetric shrinking coefficients; $V_{\max }, V_{\mathrm{w}}$, and $V_{0}$ are the volume of samples at different moisture conditions; $\beta_{V \max (\mathrm{m})}$ and $\beta_{V \mathrm{w}(\mathrm{c})}$ are the volumetric shrinking coefficients of the control and modified wood samples, respectively.

\subsection{Mechanical Property Testing}

Wood samples with the dimensions $5 \mathrm{~mm}^{3} \times 5 \mathrm{~mm}^{3} \times 10 \mathrm{~mm}^{3}(\mathrm{~T} \times \mathrm{R} \times \mathrm{L})$ were obtained for nanoindentation (NI) to evaluate the effect of modification on the wood cell wall. The transverse section of the samples was polished by an ultra-microtome with a diamond knife (Micro Star Tech Inc., Huntsville, AL, USA). As shown in Figure 1, the cell wall mechanics of both the control and modified wood, which had been equilibrated at $20^{\circ} \mathrm{C}$ and $65 \% \mathrm{RH}$ for $48 \mathrm{~h}$, were measured by using a Hysitron TriboIndenter system (Hysitron Inc., USA) equipped with scanning probe microscopy (SPM). Testing was operated with the load function: loading, holding at the peak load of $400 \mu \mathrm{N}$, and unloading for $5 \mathrm{~s}$, respectively. About 30 valid indents were obtained to calculate the reduced elastic modulus $\left(E_{\mathrm{r}}\right)$ and hardness $(H)$ based on Equations (14) and (15) introduced by Oliver and Pharr [27]:

$$
H=\frac{P_{\max }}{A}
$$

where $P_{\max }$ is the peak load, and $A$ is the projected contact area of the tips at peak load.

$$
E_{r}=\frac{\sqrt{\pi}}{2 \beta} \frac{S}{\sqrt{A}}
$$

where $E_{\mathrm{r}}$ is the combined elastic modulus; $S$ is initial unloading stiffness; and $\beta$ is a correction factor correlated to indenter geometry $(\beta=1.034)$. 

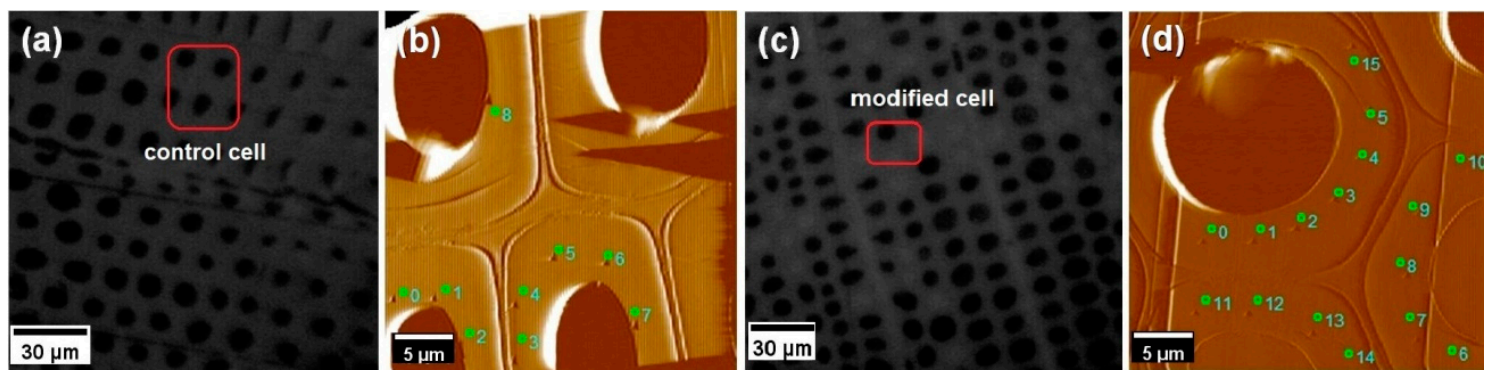

Figure 1. Microscope images showing the positioning of indents: (a) and (c) optical micrograph of the transverse section of wood samples; (b) and (d) scanning probe microscopy (SPM) images of wood cell walls after nanoindentation (NI).

The Janka hardness of a transverse section and the compressive strength parallel to the grain of the wood was determined in accordance with GB/T 1941-2009 and GB/T 1935-2009 standards, respectively. The dimensions of the samples were $30 \mathrm{~mm}^{3} \times 20 \mathrm{~mm}^{3} \times 20 \mathrm{~mm}^{3}(\mathrm{~L} \times \mathrm{T} \times \mathrm{R})$. A total of 20 replicate samples for each treatment were conditioned until they reached a moisture content of approximately $12 \%$ before testing.

\section{Results and Discussion}

\subsection{Weight Percent Gain and Density}

Figure 2 shows the weight percent gain (WPG) and density of the control and modified wood samples. It can be observed that the WPG and density increase with increasing PF concentration. Density was positively correlated with WPG, which gradually increased by $34.7 \%$ and $39.6 \%$ as compared to the control when the PF concentration was 30\%, respectively. The increased density of the samples was mainly attributed to the filling of the cell lumens with PF resin. Meanwhile, the lower increased rate of density than that of WPG may due to the swelling of cell wall filled with PF resin. However, both the WPG and density increased slowly when the PF concentration was above $20 \%$. In a previous study, the viscosity of the solution has been found to affect the penetration in wood [28,29]. That is, higher concentration PF resin could decrease the permeability of the resin in wood.

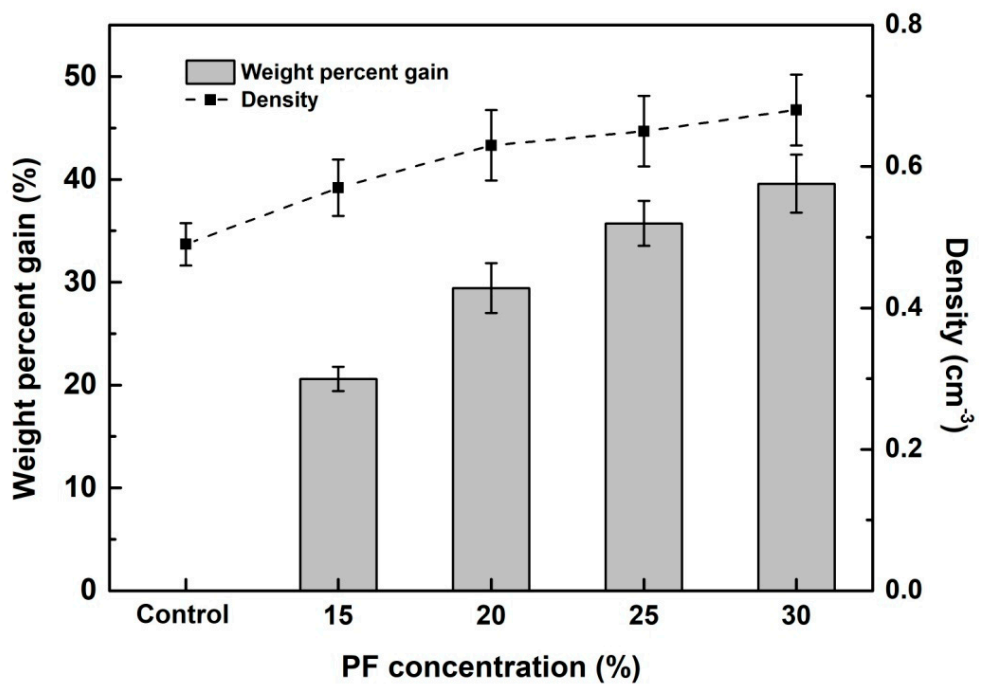

Figure 2. Weight percent gain (WPG) and density of the control and modified wood. PF = phenol formaldehyde. 


\subsection{Morphological Analysis}

The scanning electron microscopy images of the cross-sectional and tangential-sectional surfaces of the wood samples are shown in Figure 3. The presence of the polymeric structure of PF resin can be easily noted in many cell lumens and pits (Figure 3d,f). During impregnation in Masson pine wood, the chemicals entered the interior of the wood primarily through the wood tracheids and then circulated through the pits in an axial and transverse direction $[10,26]$. Under the action of exterior pressure, the PF molecules freely diffused into the intercellular spaces of the wood. It also can be observed that there is no obvious boundary between the wood cell wall and the filled PF resin, which may indicate that some PF resin has penetrated into the cell wall and that they interact with each other well. Furthermore, some cracks appear on the cell walls that are not filled with resin; however, the surface of the cell walls filled with resin was smoother and more compact after drying. This finding illustrates that the penetration of resin into the cell wall can enlarge the differences in shrinkage properties of the filled and unfilled cell walls and might be responsible for the cracks between them (Figure 3e).
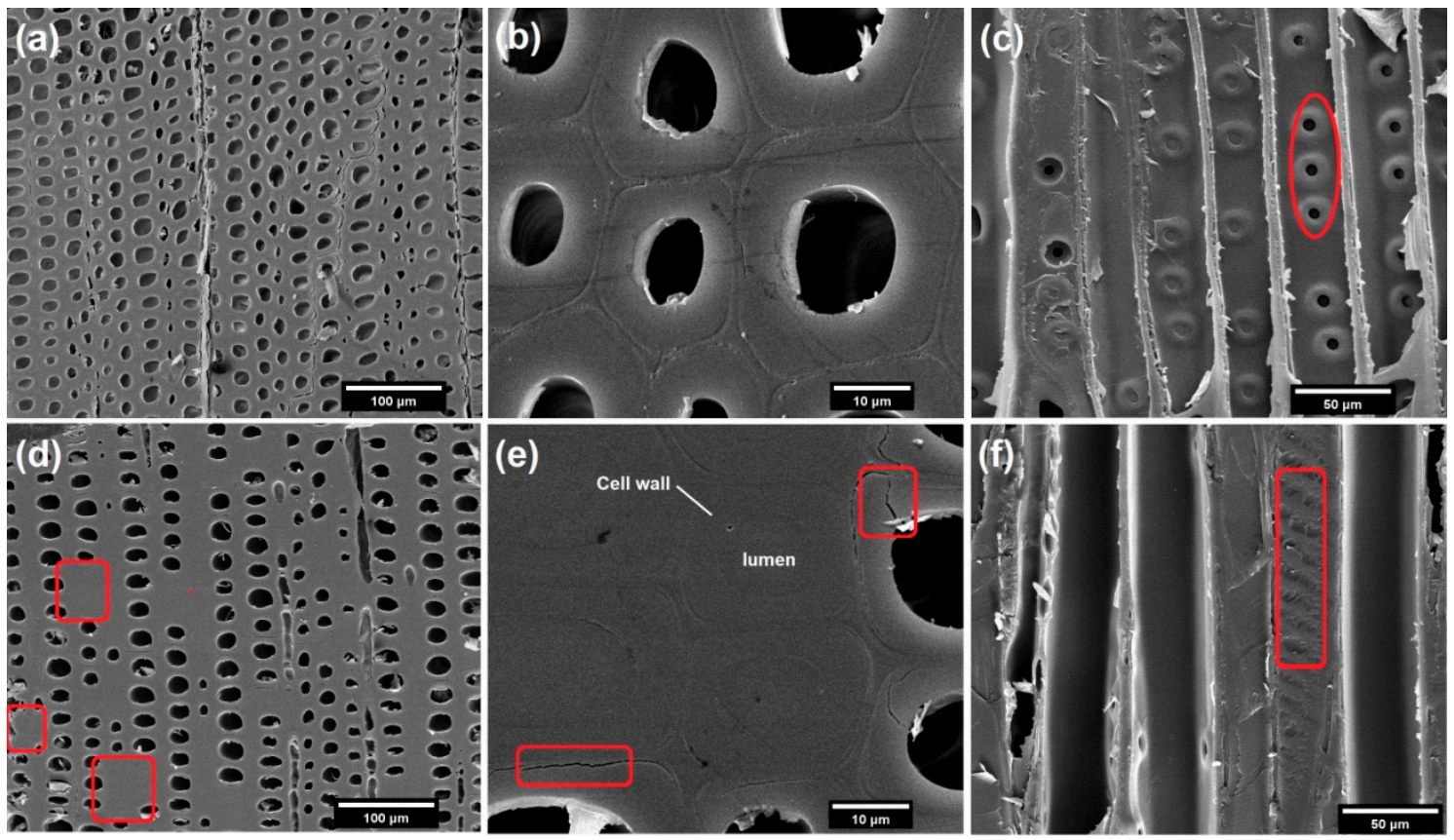

Figure 3. Micrographs of the cross-sections of $(\mathbf{a}, \mathbf{b})$ the control wood, $(\mathbf{d}, \mathbf{e})$ the wood modified by PF resin, and tangential-section of (c) the control wood, (f) the modified wood.

\subsection{Local Chemical Analysis by Raman}

Raman was used to detect the local chemical groups to confirm the possible interactions between the wood cell wall materials and the resin. Figure 4 shows the typical spectra for the control wood cell wall, PF resin within the lumen, and cell wall filled with resin. The spectra with black and blue color in Figure 4 indicate that the chemical nature of the native cell wall material is clearly different from the cured PF resin. Wood cell walls are mainly composed of cellulose, hemicelluloses, and lignin. The bands at $1091 \mathrm{~cm}^{-1}, 1336 \mathrm{~cm}^{-1}$, and $1376 \mathrm{~cm}^{-1}$ on the black IR spectra corresponded to the C-O stretching and flexural vibrations in cellulose and hemicellulose, and the absorption at $1595 \mathrm{~cm}^{-1}$ and $1656 \mathrm{~cm}^{-1}$ arises from the non-conjugated and conjugated $\mathrm{C}=\mathrm{C}$ stretching vibrations in the aromatic ring of the phenol in lignin [30-32]. For phenol formaldehyde resin, the intensive band at $1607 \mathrm{~cm}^{-1}$ originates from the $\mathrm{C}=\mathrm{C}$ stretching vibration in the aromatic ring of the phenol, while the bands at $1287 \mathrm{~cm}^{-1}$ and $778 \mathrm{~cm}^{-1}$ are attributable to the biphenyl C-C bridge stretching vibration and C-H flexural vibration in the aromatic ring. It is intriguing that a number of spectral modifications appeared on the spectra with red color for the modified cell wall, although the general aspect of the spectra remained unchanged. The intensity of the $C=C$ stretching and $C-O$ stretching at $1656 \mathrm{~cm}^{-1}, 1376 \mathrm{~cm}^{-1}$, 
and $1336 \mathrm{~cm}^{-1}$ decreased significantly, while some new bands at $1287 \mathrm{~cm}^{-1}$ and $778 \mathrm{~cm}^{-1}$ appeared as compared to the control cell wall, which can be attributed to the penetration of PF resin into the cell wall [33,34]. Moreover, a relatively broader band between $1150 \mathrm{~cm}^{-1}$ and $1100 \mathrm{~cm}^{-1}$ appeared in the spectra of modified wood, corresponding to the asymmetric stretching vibration of C-O-C aliphatic ether, which is in agreement with the literature that the chemical reactions of the -OH groups of wood and PF resin occurred at the cell wall level $[35,36]$.

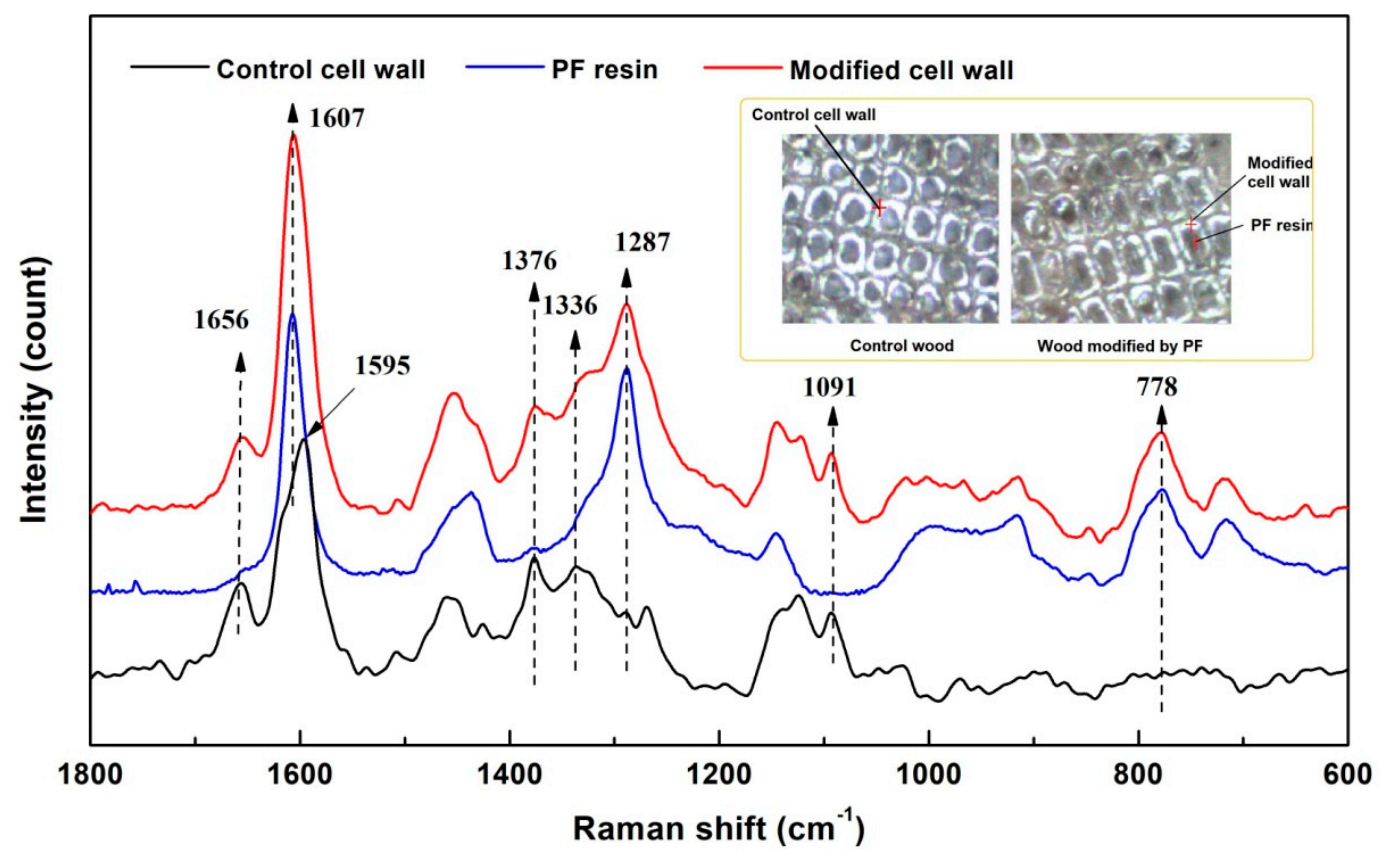

Figure 4. Raman spectra of the control and modified wood.

\subsection{Dimensional Stability}

The swelling and shrinking coefficients $(\alpha$ and $\beta$ ) of the control and chemically modified wood samples under different moisture conditions are presented in Figure 5. The swelling and shrinking coefficients of wood with the changing moisture content (MC) between oven-dried and air-dried conditions $\left(\alpha_{\mathrm{w}}\right.$ and $\beta_{\mathrm{w}}$ ) were primarily measured to evaluate the dimensional stability of wood applied on locations with low equilibrium moisture content. Both the $\alpha_{\mathrm{w}}$ and $\beta_{\mathrm{w}}$ in the radial direction were about half of that in the tangential direction, resulting from the anatomical structures such as the limitation of xylem ray, the difference of lignin content in the radial and tangential cell wall, etc. [10]. The $\alpha_{\mathrm{w}}$ and $\beta_{\mathrm{w}}$ decreased significantly at first and then kept stable with an increase in PF resin concentration in comparison with the control, indicating that chemical treatment could effectively improve wood dimensional stability [19]. The radial, tangential, and volumetric $\alpha_{\mathrm{w}} \mathrm{s}$ of wood modified by PF resin with $20 \%$ concentration were about $45 \%, 58 \%$, and $54 \%$ lower than that of the control, respectively. However, the $\beta_{\mathrm{w}}$ became stable when the PF concentration was beyond $15 \%$, indicating that PF resin concentrations ranging from $15 \%$ to $20 \%$ are better for wood impregnation.

As applied in areas with a larger moisture content range, such as outdoors, the swelling and shrinking coefficients of wood with the changing MC between oven-dried and wet conditions $\left(\alpha_{\max }\right.$ and $\beta_{\max }$ ) need to be analyzed too. It can be observed from Figure $5 \mathrm{c}$ and $5 \mathrm{~d}$ that the effect of PF resin impregnation on the $\alpha_{\max }$ and $\beta_{\max }$ is similar to that of $\alpha_{\mathrm{w}}$ and $\beta_{\mathrm{w}}$; that is, the dimensional stability of wood can be modified effectively by the PF resin at concentrations below $20 \%$. The radial, tangential, and volumetric $\beta_{\max }$ s of wood modified by PF resin at $20 \%$ concentration decreased by about $49 \%$, $50 \%$, and 51\%, respectively. Moreover, both the $\alpha_{\max }$ and $\beta_{\max }$ were almost twice as high as the $\alpha_{\mathrm{w}}$ and $\beta_{\mathrm{w}}$, respectively, which can be attributed to the different moisture content. The MC of air-dried wood is approximately $12-15 \%$, which is half of the fiber saturation point (FSP). Generally, the hygroscopic 
water located within the cell wall plays the most important role on the dimension stability rather than the free water occupied in the cell lumen or other macro-voids.
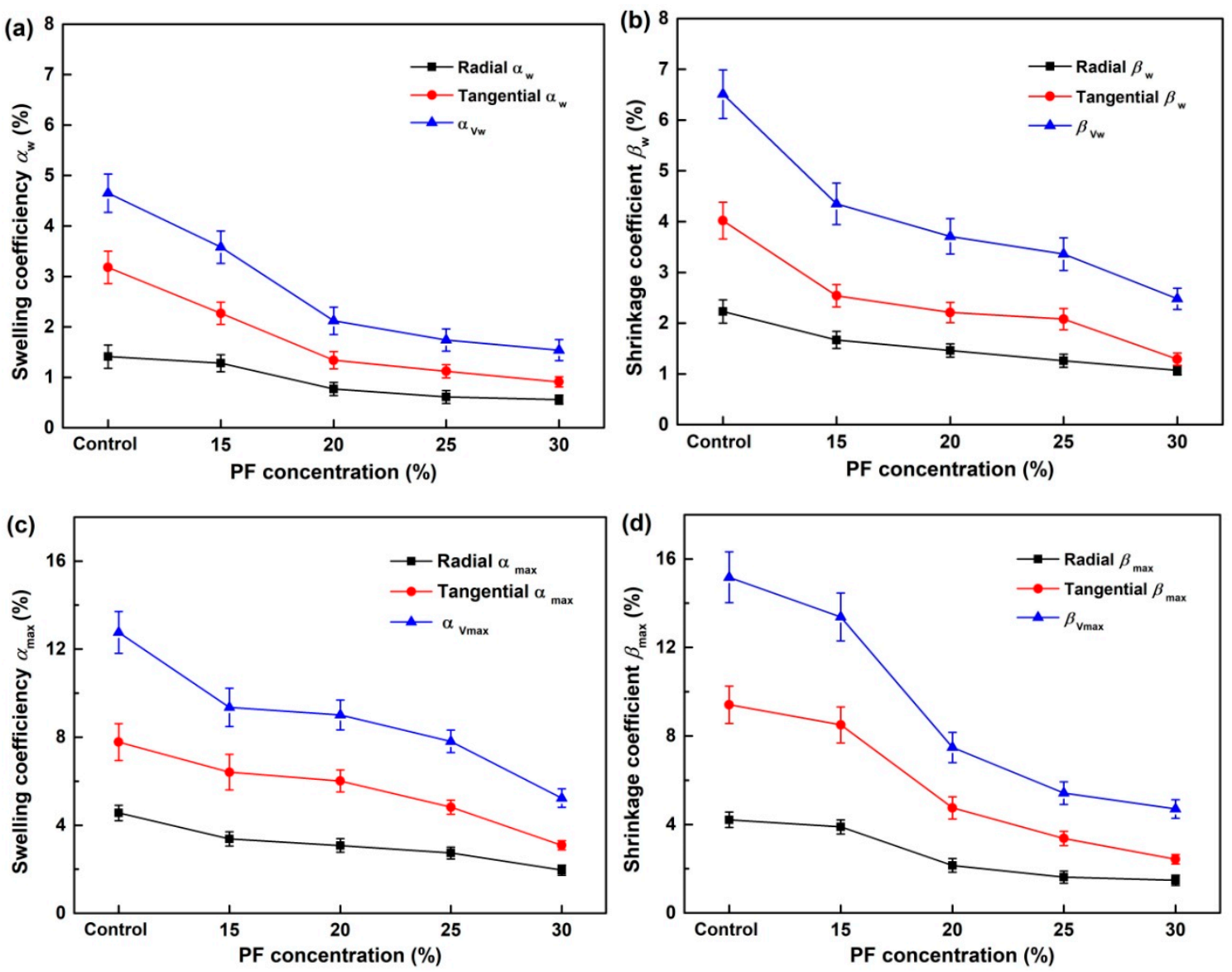

Figure 5. The swelling and shrinking coefficients of the control and modified wood: (a) and (b) swelling and shrinking coefficients from oven-dried to wet; (c) and (d) swelling and shrinking coefficients from oven-dried to air-dried.

The anti-swelling efficiency (ASE) and anti-shrinking efficiency (ASE') were positively affected by the PF resin concentration (Figure 6). The $\mathrm{ASE}_{\mathrm{W}}$ and $\mathrm{ASE}_{\mathrm{w}}^{\prime}$ initially increased at a concentration of $20 \%$ and then kept stable or only increased slightly with a further increase in concentration. The $\mathrm{ASE}_{\mathrm{w}}$ and $\mathrm{ASE}^{\prime}{ }_{\mathrm{w}}$ of the wood treated with $20 \%$ PF resin reached $54 \%$ and $50 \%$, respectively. The deposition of PF in the cell walls reduced the space within the cell walls, which could be occupied by water in untreated wood. In addition, the reduction in swelling and shrinking of the modified wood could be partly attributed to cross-linking of particle cell wall polymers [37,38]. However, the ASE max $_{\text {ax }}$ and ASE' $_{\text {max }}$ of the wood kept increasing with the increased concentration and reached the maximum of $59 \%$ and $62 \%$ as PF resin concentration increased to $30 \%$. As the MC of wood exceeded the FSP, the free voids in the wood provided space for free water, which also affected the swelling and shrinking. Thus, the higher WPG attributed to the higher PF resin concentration could occupy more free space and finally increase the $\mathrm{ASE}_{\max }$ and $\mathrm{ASE}_{\text {max }}$. The $\mathrm{ASE}_{\mathrm{w}}$ and $\mathrm{ASE}_{\mathrm{w}}{ }_{\mathrm{w}}$ of the wood treated with $20 \% \mathrm{PF}$ resin is close to the maximum $\mathrm{ASE}_{\max }$ and $\mathrm{ASE}_{\max }$, indicating that the lower concentration $\mathrm{PF}$ resin is suitable for treating the wood utilized in areas with small MC range. 

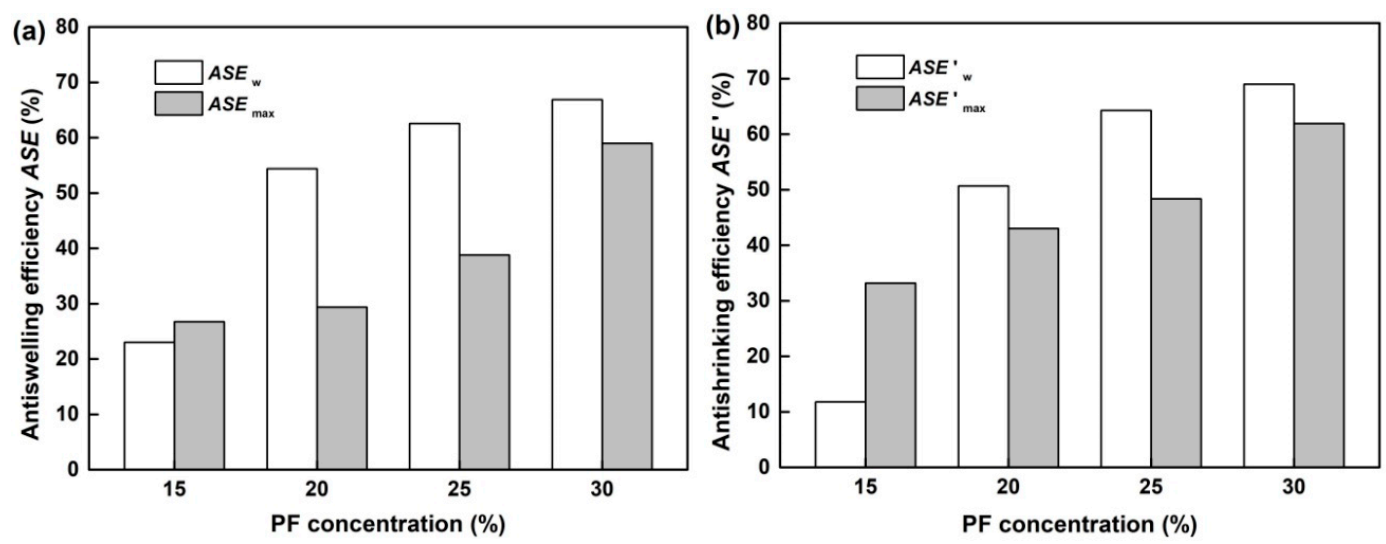

Figure 6. The anti-swelling and anti-shrinking efficiency of the modified wood: (a) anti-swelling efficiency; (b) anti-shrinking efficiency.

\subsection{Micro-Mechanics of Wood Cell Walls}

The longitudinal reduced elastic modulus $\left(E_{\mathrm{r}}\right)$ and hardness $(H)$ of the control and modified wood cell walls are presented in Figure 7, respectively. It is remarkable that the $E_{\mathrm{r}}$ and $H$ values increased after impregnation by PF resin. For instance, the $E_{\mathrm{r}}$ and $H$ values of the wood cell walls modified with PF resin at $15 \%$ concentration increased by about $24.9 \%$ and $47.3 \%$, which further confirmed the results of the Raman measurements that some PF molecules penetrated into the cell wall successfully. The filling of the voids and the cross-linking of $-\mathrm{OH}$ groups of the wood polymer with the resins may reinforce the cell wall $[39,40]$. However, the cell wall mechanics increased slowly and even decreased accompanying the increase in PF resin concentration. The $E_{\mathrm{r}}$ and $H$ of the wood cell walls modified by $30 \%$ PF resin were $8.7 \%$ and $11.6 \%$ lower than that of the cell wall modified by $20 \%$ PF, which can be easily interpreted as a result of the increasing bulking effects attributed to the deposition of resin in the cell walls at higher WPG.

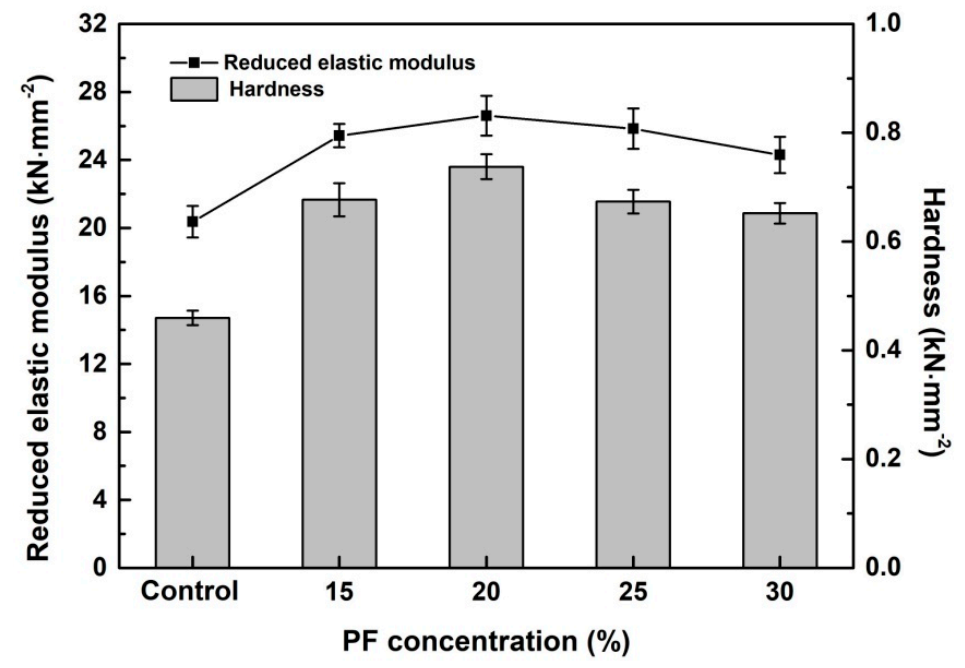

Figure 7. The reduced elastic modulus and hardness of the control and modified wood cell walls.

\subsection{Macro-Mechanics of Wood}

Figure 8 shows the hardness of the transverse section and the compressive strength parallel to grain of the control and modified wood at the macro-level. The initial hardness and compressive strengths of the control wood are $39.5 \mathrm{~N} \cdot \mathrm{mm}^{-2}$ and $49.1 \mathrm{~N} \cdot \mathrm{mm}^{-2}$, respectively. Both the hardness and compressive strength gradually increased with an increase in PF resin concentration, reaching the maximum of $54.9 \mathrm{~N} \cdot \mathrm{mm}^{-2}$ and $59.7 \mathrm{~N} \cdot \mathrm{mm}^{-2}$ with a concentration of $30 \%$. The higher filling degree of the wood voids led to a higher density, which mainly contributed to the improved hardness and 
compressive strength after curing of the PF resin [41]. In addition, the increased mechanics of wood cell walls induced by the chemical modification also played an important role to achieve the desired modification effect. However, as the PF concentration was above $20 \%$, the hardness and compressive strength kept stable, which was in agreement with the results of dimensional stability and cell wall mechanics. That is, the PF concentration of $20 \%$ may be preferred to modify Masson pine wood.

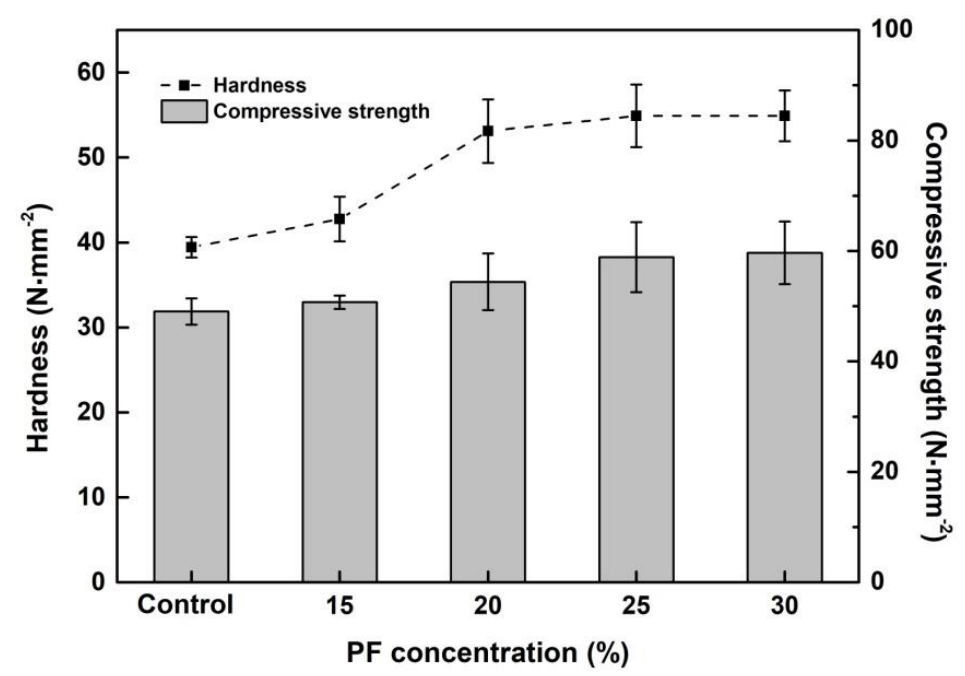

Figure 8. The compressive strength and hardness of the control and modified wood.

\section{Conclusions}

The effects of PF resin impregnation on the density, dimensional stability, mechanical strength, and microscopic chemical and mechanical properties of Masson pine wood were determined in this paper. PF resin was impregnated into the wood cell lumen and diffused into the cell walls, as verified by scanning electron microscopy and Raman spectrum. Swelling and shrinking coefficients were significantly reduced while the anti-swelling and anti-shrinking efficiency of wood were improved accompanying the increase in PF resin concentration. The inter-reaction between the resin and cell walls made a positive contribution to the cell wall mechanics of wood cell walls. The elastic modulus $\left(E_{\mathrm{r}}\right)$ and hardness $(H)$ of the wood cell walls modified by $15 \%$ PF resin increased by about $24.9 \%$ and $47.3 \%$ as compared to the control. Both the increased density attributed to the filling of resin in cell lumens and cell walls and the improved cell wall mechanics resulted in the remarkable increase in hardness and the compress strength of wood. However, both the dimensional stability and mechanical properties improved slowly as the PF concentration was above $20 \%$; that is, the PF concentration of $20 \%$ may be preferred to modify Masson pine wood.

Author Contributions: X.W. conceived and designed the experiments; X.C. and S.C. performed the experiments; X.C., X.X., and Z.Y. analyzed the data; X.W. wrote the paper, with revisions by Y.L.

Acknowledgments: The authors would like to gratefully acknowledge the financial support from the Natural Science Foundation of Jiangsu Province (BK20180774), Natural Science Foundation of China (31570552), and Key University Science Research Project of Jiangsu Province (17KJA220004).

Conflicts of Interest: The authors declare no conflict of interest.

\section{References}

1. Gu, H.; Wang, J.; Ma, L.; Shang, Z.; Zhang, Q. Insights into the BRT (Boosted Regression Trees) method in the study of the climate-growth relationship of Masson pine in subtropical China. Forests 2019, 10, 228. [CrossRef]

2. He, Q.; Zhan, T.; Ju, Z.; Zhang, H.; Hong, L.; Brosse, N.; Lu, X. Influence of high voltage electrostatic field (HVEF) on bonding characteristics of Masson (Pinus massoniana Lamb.) veneer composites. Eur. J. Wood Wood Prod. 2019, 77, 105-114. [CrossRef] 
3. Ge, S.; Ma, J.; Jiang, S.; Liu, Z.; Peng, W. Potential use of different kinds of carbon in production of decayed wood plastic composite. Arab. J. Chem. 2018, 11, 838-843. [CrossRef]

4. Wang, X.; Chen, X.; Xie, X.; Wu, Y.; Zhao, L.; Li, Y.; Wang, S. Effects of thermal modification on the physical, chemical and micromechanical properties of Masson pine wood (Pinus massoniana Lamb.). Holzforschung 2018, 72, 1063-1070. [CrossRef]

5. Li, W.; Wang, H.; Ren, D.; Yu, Y.; Yu, Y. Wood modification with furfuryl alcohol catalysed by a new composite acidic catalyst. Wood Sci. Technol. 2015, 49, 845-856. [CrossRef]

6. Altgen, M.; Hofmann, T.; Militz, H. Wood moisture content during the thermal modification process affects the improvement in hygroscopicity of Scots pine sapwood. Wood Sci. Technol. 2016, 50, 1-15. [CrossRef]

7. Gaff, M.; Babiak, M.; Kačík, F.; Sandberg, D.; Turčani, M.; Hanzlík, P.; Vondrová, V. Plasticity properties of thermally modified timber in bending-The effect of chemical changes during modification of European oak and Norway spruce. Compos. Part B Eng. 2019, 165, 613-625. [CrossRef]

8. Shi, J.; Lu, Y.; Zhang, Y.; Cai, L.; Shi, S.Q. Effect of thermal treatment with water, $\mathrm{H}_{2} \mathrm{SO}_{4}$ and $\mathrm{NaOH}$ aqueous solution on color, cell wall and chemical structure of poplar wood. Sci. Rep. 2018, 8, 17735. [CrossRef]

9. Wu, Y.; Wu, J.; Wang, S.; Feng, X.; Chen, H.; Tang, Q.; Zhang, H. Measurement of mechanical properties of multilayer waterborne coatings on wood by nanoindentation. Holzforschung 2019. [CrossRef]

10. Cai, M.; Fu, Z.; Cai, Y.; Li, Z.; Xu, C.; Xu, C.; Li, S. Effect of impregnation with maltodextrin and 1,3-dimethylol-4,5-dihydroxyethyleneurea on Poplar wood. Forests 2018, 9, 676. [CrossRef]

11. Gérardin, P. New alternatives for wood preservation based on thermal and chemical modification of wood-a review. Ann. For. Sci. 2016, 73, 559-570. [CrossRef]

12. Sandberg, D.; Kutnar, A.; Mantanis, G. Wood modification technologies-A review. iForest 2017, 10, 895-908. [CrossRef]

13. Li, W.; Jan, V.D.B.; Dhaene, J.; Zhan, X.; Mei, C.; Van Acker, J. Investigating the interaction between internal structural changes and water sorption of mdf and OSB using X-ray computed tomography. Wood Sci. Technol. 2018, 52, 701-716. [CrossRef]

14. Yue, K.; Chen, Z.; Lu, W.; Liu, W.; Li, M.; Shao, Y.; Tang, L.; Wan, L. Evaluating the mechanical and fire-resistance properties of modified fast-growing Chinese fir timber with boric-phenol-formaldehyde resin. Constr. Build. Mater. 2017, 154, 956-962. [CrossRef]

15. Sun, S.; Zhao, Z. Influence of acid on the curing process of tannin-sucrose adhesives. BioResources 2018, 13, 7683-7697. [CrossRef]

16. Shams, M.I.; Morooka, T.; Yano, H. Compressive deformation of wood impregnated with low molecular weight phenol formaldehyde (PF) resin V: Effects of steam pretreatment. J. Wood Sci. 2006, 52, 389-394. [CrossRef]

17. Khalil, H.A.; Amouzgar, P.; Jawaid, M.; Abdullah, C.; Issam, A.; Zainudin, E.; Paridah, M.T.; Hassan, A. Physical and thermal properties of microwave-dried wood lumber impregnated with phenol formaldehyde resin. J. Compos. Mater. 2013, 47, 3565-3571. [CrossRef]

18. Biziks, V.; Bicke, S.; Militz, H. Penetration depth of phenol-formaldehyde (PF) resin into beech wood studied by light microscopy. Wood Sci. Technol. 2018, 53, 165-176. [CrossRef]

19. Deka, M.; Saikia, C.N. Chemical modification of wood with thermosetting resin: Effect on dimensional stability and strength property. Bioresour. Technol. 2000, 73, 179-181. [CrossRef]

20. Özçifçi, A. Impacts of impregnation with boron compounds on the bonding strength of wood materials. Constr. Build. Mater. 2008, 22, 541-545. [CrossRef]

21. Devi, R.R.; Ali, I.; Maji, T. Chemical modification of rubber wood with styrene in combination with a crosslinker: Effect on dimensional stability and strength property. Bioresour. Technol. 2003, 88, 185-188. [CrossRef]

22. Yildiz, U.C.; Yildiz, S.; Gezer, E.D. Mechanical properties and decay resistance of wood-polymer composites prepared from fast growing species in Turkey. Bioresour. Technol. 2005, 96, 1003-1011. [CrossRef]

23. Gindl, W.; Schoberl, T. The significance of the elastic modulus of wood cell walls obtained from nanoindentation measurements. Compos. Part A 2004, 35, 1345-1349. [CrossRef]

24. Wimmer, R.; Lucas, B.N.; Tsui, T.Y.; Oliver, W.C. Longitudinal hardness and young's modulus of spruce tracheid secondary walls using nanoindentation technique. Wood Sci. Technol. 1997, 31, 131-141. [CrossRef] 
25. Yu, Y.; Fei, B.; Wang, H.; Tian, G. Longitudinal mechanical properties of cell wall of Masson pine (Pinus massoniana Lamb) as related to moisture content: A nanoindentation study. Holzforschung 2011, 65, 121-126. [CrossRef]

26. Ali, E.M. Modification of spruce wood by UV-crosslinked PEG hydrogels inside wood cell walls. React. Funct. Polym. 2018, 131, 100-106.

27. Oliver, W.C.; Pharr, G.M. An improved technique for determining hardness and elastic modulus using load and displacement sensing indentation experiments. J. Mater. Res. 1992, 7, 1564-1583. [CrossRef]

28. Xie, Y.; Xiao, Z.; Grüneberg, T.; Militz, H.; Hill, C.A.; Steuernagel, L.; Mai, C. Effects of chemical modification of wood particles with glutaraldehyde and 1,3-dimethylol-4,5-dihydroxyethyleneurea on properties of the resulting polypropylene composites. Compos. Sci. Technol. 2010, 70, 2003-2011. [CrossRef]

29. Xie, Y.; Fu, Q.; Wang, Q.; Xiao, Z.; Militz, H. Effects of chemical modification on the mechanical properties of wood. Eur. J. Wood Wood Prod. 2013, 71, 401-416. [CrossRef]

30. Tjeerdsma, B.F.; Militz, H. Chemical changes in hydrothermal treated wood: FTIR analysis of combined hydrothermal and dry heat-treated wood. Holz Roh. Werkst. 2005, 63, 102-111. [CrossRef]

31. González-Peña, M.M.; Curling, S.F.; Hale, M.D. On the effect of heat on the chemical composition and dimensions of thermally-modified wood. Polym. Degrad. Stab. 2009, 94, 2184-2193. [CrossRef]

32. Kotilainen, R.A.; Toivanen, T.J.; Alén, R.J. FTIR monitoring of chemical changes in softwood during heating. J. Wood Chem. Technol. 2000, 20, 307-320. [CrossRef]

33. Krajnc, M.; Poljanšek, I. Characterization of phenol-formaldehyde prepolymer resins by in line FTIR spectroscopy. Acta Chim. Slov. 2015, 52, 238-244.

34. De, D.; Adhikari, B.; De, D. Grass fiber reinforced phenol formaldehyde resin composite: Preparation, characterization and evaluation of properties of composite. Polym. Adv. Technol. 2007, 18, 72-81. [CrossRef]

35. Wang, X.; Deng, Y.; Li, Y.; Kjoller, K.; Roy, A.; Wang, S. In situ identification of the molecular-scale interactions of phenol-formaldehyde resin and wood cell walls using infrared nanospectroscopy. RSC Adv. 2016, 6, 76318-76324. [CrossRef]

36. Paris, J.L.; Kamke, F.A.; Xiao, X. X-ray computed tomography of wood-adhesive bondlines: Attenuation and phase-contrast effects. Wood Sci. Technol. 2015, 49, 1185-1208. [CrossRef]

37. Yelle, D.J.; Ralph, J. Characterizing phenol-formaldehyde adhesive cure chemistry within the wood cell wall. Int. J. Adhes. Adhes. 2016, 70, 26-36. [CrossRef]

38. Wang, J.; Laborie, M.P.G.; Wolcott, M.P. Correlation of mechanical and chemical cure development for phenol-formaldehyde resin bonded wood joints. Thermochimica Acta 2011, 513, 20-25. [CrossRef]

39. Jakes, J.E.; Hunt, C.G.; Yelle, D.J.; Lorenz, L.; Hirth, K. Synchrotron-based X-ray fluorescence microscopy in conjunctionwith nanoindentation to study molecular-scale interactions of phenol-formaldehyde in wood cell walls. ACS Appl. Mater. Interfaces 2015, 7, 6584-6589. [CrossRef]

40. Kuai, B.; Wang, X.; Lv, C.; Xu, K.; Zhang, Y.; Zhan, T. Orthotropic tension behavior of two typical chinese plantation woods at wide relative humidity range. Forests 2019, 10, 516. [CrossRef]

41. Olaniran, S.O.; Michen, B.; Mora Mendez, D.F.; Wittel, F.K.; Bachtiar, E.V.; Burgert, I.; Markus, R. Mechanical behaviour of chemically modified Norway spruce (Picea abies L. karst.): Experimental mechanical studies on spruce wood after methacrylation and in situ polymerization of styrene. Wood Sci. Technol. 2019, 53, 425-445. [CrossRef]

(C) 2019 by the authors. Licensee MDPI, Basel, Switzerland. This article is an open access article distributed under the terms and conditions of the Creative Commons Attribution (CC BY) license (http://creativecommons.org/licenses/by/4.0/). 